\title{
EVALUATION OF KINETIC PARAMETERS AND REDOX MECHANISM OF QUINOXALINE AT GLASSY CARBON ELECTRODE
}

\author{
UDC $544.3: 547.863 .11$
}

\author{
Mara M. Aleksić ${ }^{1}$, Jelena Pantić ${ }^{2}$, Vera P. Kapetanović ${ }^{3}$ \\ ${ }^{1}$ University of Belgrade, Faculty of Pharmacy, \\ Department of Physical Chemistry and Instrumental methods, Belgrade, Serbia \\ ${ }^{2}$ University of Belgrade, Faculty of Pharmacy, Belgrade, Serbia \\ ${ }^{3}$ University of Belgrade, Faculty of Pharmacy, Department of Analytical Chemistry, \\ Belgrade, Serbia
}

\begin{abstract}
The electrochemical behavior of a biologically important heterocyclic compound quinoxaline (QUI) was investigated by cyclic voltammetry $(\mathrm{CV})$ in solutions of differing $\mathrm{pH}$, using a glassy carbon electrode (GCE). The reduction of QUI occurs as a quasi-reversible reaction in acid medium, reaching reversibility in alkaline solutions. The kinetic parameters of the electrode process such as $\alpha n_{o}$, diffusion coefficient $(D)$ and heterogeneous rate constant $\left(k_{s}\right)$, were evaluated and discussed. Redox mechanism of QUI was proposed on the basis of experimental results. Reduction process involves a transfer of two electrons and two protons at the pyrazine ring of QUI forming a dihydro-derivative. In acid solutions, the product of QUI reduction undergoes irreversible oxidation in a one-electron process. The electrode processes was found to be diffusion controlled.
\end{abstract}

Key words: Quinoxaline, cyclic voltammetry, glassy carbon electrode, redox mechanism, kinetic parameters

\section{INTRODUCTION}

Heterocyclic compounds (HCs) have drawn the utmost attention of researchers due to their extensive practical applications. Synthetic heterocycles are widely used as fungicides, herbicides, antioxidant and flavoring agents [1]. Not only some natural drugs i.e. quinine, theophylline, theobromine, emetine, atropine, and morphine [2-5]have heterocyclic cores in their structure, HCs are lead structures for the designing synthetic drugs [6]. Many of nitrogen containing heterocyclic compounds have been reported to be

Received September 23 ${ }^{\text {th }}, 2014$; revised November 11 $1^{\text {th }}, 2014$; accepted November $28^{\text {th }}, 2014$.

Corresponding author: Mara M. Aleksić

University of Belgrade, Faculty of Pharmacy, Department of Physical Chemistry and Instrumental methods,

Vojvode Stepe 450, P.O. Box 146, 11221 Belgrade, Serbia

E-mail: mara@pharmacy.bg.ac.rs 
carcinogenic or increase the carcinogenic activity [7]. Quinoxaline (QUI), also called benzopyrazine (Fig. 1.) is heterocyclic compound containing fused benzene and pyrazine rings. Many important biologically active compounds are derivatives of this heterocycle. It is known antibiotic activity of actinomycin, lomacine and actinolite is related to the presence of quinoxaline ring in their structures [8]. Similar is true for active principle of some preparations for smoking cessation (e.g. varenicline) and antiglaucoma agents (brimonidine) [9,10]; QUI related compound has been recently used as an antineoplastic drug [11] in cancer treatment.

The electrochemical behavior of QUI was studied using mercury electrode [12-14]. According to literature [12], the electrode reaction corresponding to the two polarographic reduction waves of quinoxaline at DME (1,2-dimetoxyetane) is ascribed to the reduction of two $\mathrm{C}=\mathrm{N}$ bonds of the quinoxaline ring. In two consecutive one electron steps, $\mathrm{C}=\mathrm{N}$ bonds in $\mathrm{QUI}$ are reduced to 1,4-dihydroquinoxaline which further undergoes $\mathrm{H}^{+}$- catalyzed chemical transformation, and after the addition of two protons and two electrons it is reduced to final product - 1,2,3,4-tetrahydroquinoxaline. Murray and coworkers [13] showed that the critical factor in governing the reduction process of quinoxalines is the $\mathrm{pH}$ of the solution. Overall process is possible only in strong acid solution, while in neutral and alkaline medium dihydroquinoxaline is formed as a final product which can be reversibly oxidized back to QUI.

However, as the use of mercury electrode is limited to the negative potential range, the information obtained allowed conclusions only about the reduction of QUI. There are no literature data about QUI oxidation and electrochemical behavior at solid electrodes. To bridge this gap, the present study is aimed at the investigation of the QUI redox processes using cyclic voltammetry at a glassy carbon electrode in a wide $\mathrm{pH}$ range, and evaluation of kinetic parameters of its redox reactions.

\section{MATERIALS AND METHODS}

\subsection{Instrumentation}

The voltammetric measurements were performed with an $\mu$ Autolab analyzer (EcoChemie, Utrecht, The Nederlands) running with the GPES 4.9 software. Three-electrode system was employed: glassy carbon electrode (GCE produced by $\mathrm{CH}$ Instruments, Inc., USA, $\mathrm{d}=3 \mathrm{~mm}(\mathrm{~A}=0.071 \mathrm{~cm} 2))$ as working electrode, an $\mathrm{Ag} / \mathrm{AgCl}$ as reference electrode $\left(3\right.$ moldm $\left.^{-3} \mathrm{KCl}\right)$ and Pt-auxiliary electrode.

A SCALTEC SBC 31 balance, Ultrasonic bath "Iskra" UZ 4R and Radiometer pH meter, PHM 220, with combined $\mathrm{pH}$ electrode Radiometer GK2401B and appropriate standard buffer solutions were used.<smiles>c1ccc2nccnc2c1</smiles>

Fig. 1 Structure of quinoxaline (QUI)

The GCE was manually polished using the aqueous slurry of $\mathrm{Al}_{2} \mathrm{O}_{3}$ powder (particle size $0.05 \mu \mathrm{m}$ ) on a smooth polishing pad before each experiment. The electrode was rinsed with bidistilled water and then sonicated in absolute ethanol for $2 \mathrm{~min}$.

\subsection{Chemicals}

Quinoxaline standard was produced by Sigma Aldrich. A stock solution of $2 \times 10^{-3} \mathrm{moldm}^{-3}$ QUI was prepared in bidistilled water. The solutions of different concentrations were obtained by diluting the stock solution with different supporting electrolytes [15], and prepared from 
the chemicals of analytical grade quality. The following supporting electrolytes were used: $\mathrm{HCl}+\mathrm{KCl}$ for $\mathrm{pH} 1.9,2.2$; acetate buffer for $\mathrm{pH} 3.6,4.6$, and 5.4; phosphate buffer for $\mathrm{pH}$ 6.2, 7.0 and 8.0, and ammonia buffer for $\mathrm{pH} \mathrm{8.5,} 9.2$ and 10.2. Ionic strength of all solutions was adjusted to $0.1 \mathrm{moldm}^{-3}$. All the experiments were done at room temperature $\left(25 \pm 1^{\circ} \mathrm{C}\right)$.

\subsection{Procedures}

An appropriate volume of supporting electrolyte of different pHs were placed in electrochemical cell, deaerated for 10 minutes with high purity nitrogen and QUI stock solution was added to make its final concentration of $1 \times 10^{-4} \mathrm{moldm}^{-3}$ in a total volume of 15.0 $\mathrm{mL}$. The cyclic voltammograms were recorded between $-1.6 \mathrm{~V}$ and $+1.35 \mathrm{~V}$, at scan rate ranged $10-100 \mathrm{mVs}^{-1}$. The experimental parameters for DPV were: pulse width $50 \mathrm{~ms}$, scan rate $5 \mathrm{mVs}^{-1}$ and pulse amplitude $50 \mathrm{mV}$.

\section{RESULTS AND DiSCUSSION}

\subsection{Reduction and oxidation processes}

The redox behavior of $1 \times 10^{-4}$ moldm $^{-3}$ QUI was initially studied by $\mathrm{CV}$ in 0.1 moldm ${ }^{-3}$ acetate buffer $\mathrm{pH}$ 5.4. The cyclic voltammograms were recorded in three successive scans starting from $0.0 \mathrm{~V}$, towards $-1.35 \mathrm{~V}$ and reversing to the positive potential limit of +1.45 $\mathrm{V}$, at a scan rate $100 \mathrm{mVs}^{-1}$. On the first negative-going scan, one cathodic peak (Ic) was obtained at $E_{\mathrm{p}, \mathrm{Ic}}=-0.60 \mathrm{~V}$. Changing the scan direction, one main anodic peak (Ia) appeared at $E_{\mathrm{p}, \mathrm{Ia}}=-0.55 \mathrm{~V}$ and one additional anodic peak (IIa) at potential $E_{\mathrm{p}, \mathrm{II}}=+0.15 \mathrm{~V}$ were noticed. Recording the cyclic voltammograms in the opposite direction starting from $0.0 \mathrm{~V}$ going to $+1.45 \mathrm{~V}$ and reversing to $-1.35 \mathrm{~V}$ under the same conditions, the second anodic peak (IIa) was not present in the first scan, but it appeared in the second and third scan (Fig. 2A.). All recorded $\mathrm{CVs}$ at different $\mathrm{pH}$ values indicate the same behavior: the irreversibility of process represented by second anodic peak $\left(\mathrm{II}_{\mathrm{a}}\right)$, and the partial reversibility (increasing with $\mathrm{pH}$ ) of the process represented by cathodic and first anodic peaks (Ic and Ia). Some representative $\mathrm{CV}$ curves at different $\mathrm{pH}$ values are presented in Figure 2B.
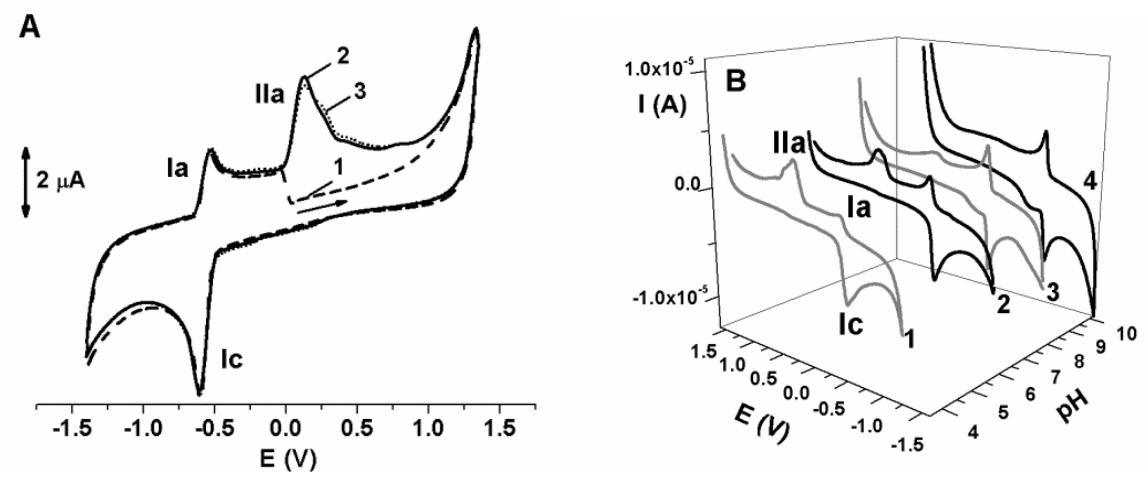

Fig. $2 \mathrm{CV}$ of $1 \times 10^{-4}$ moldm $^{-3}$ QUI at scan rate of $v=100 \mathrm{mVs}^{-1}$; (A) $\mathrm{pH} 5.4$; (---) first, (-) second and ( ...) third scan in the positive direction; (B) 1 - $\mathrm{pH} 3.6 ; 2$ - $\mathrm{pH}$ 6.2; 3 - pH 8.0 and 4 - pH 10.2. 
The reduction peak (Ic) exists at all investigated $\mathrm{pH}$ values (from 2.0 to 10.0 ), and the peak potential was shifted to more negative values with increasing $\mathrm{pH}$ (Fig. 3A).The linear dependence of $E \mathrm{p}$ vs. $\mathrm{pH}$ was obtained following the equations: $E_{\mathrm{p}, \mathrm{Ic}}=-0.339 \mathrm{~V}-$ $0.051 \mathrm{~V} \times \mathrm{pH}$, and the slope of $51 \mathrm{mV}$ suggested the same number of electrons and protons involved in the reduction process.

For a diffusion-controlled system difference between peak potential and half-height peak potential is equal to $\left|E_{\mathrm{p}}-E_{\mathrm{p} 1 / 2}\right|=47.7 /\left(\alpha \mathrm{n}_{\alpha}\right)$ [16], and the obtained values are given in Table 1. Considering the charge transfer coefficient, $\alpha=0.5$ for irreversible and $\alpha=1.0$ for reversible process, the number of the transferred electrons is calculated and the obtained values are in the range from 1.59 to 2.38 , depending on $\mathrm{pH}$, what leads to the conclusion that two electrons are involved in the reduction process.

The current of the cathodic peak Ic is $\mathrm{pH}$ dependent. After recording successive scans in the same solution without cleaning the electrode surface, the currents of cathodic peak were not changed (Figure 2A), suggesting that electrode reaction product was not adsorbed at the electrode surface.

Cyclic voltammograms were recorded at different scan rates ranged from 10 to $100 \mathrm{mVs}^{-1}$. A linear dependence of $\log I_{\mathrm{p}, \mathrm{Ic}} \mathrm{Vs} . \log v$ was obtained at all investigated $\mathrm{pH}$. The following regression equations, $\log I_{\mathrm{p}, \mathrm{Ic}}=1.025+0.341 \log v(\mathrm{r}=0.9881), \log I_{\mathrm{p}, \mathrm{Ic}}=$ $1.105+0.408 \log v(\mathrm{r}=0.9877), \log I_{\mathrm{p}, \mathrm{Ic}}=1.191+0.496 \log v(\mathrm{r}=0.9922)$ and $\log I_{\mathrm{p}, \mathrm{Ic}}=$ $1.031+0.456 \log v(r=0.9949)$ were obtained at $\mathrm{pH} 1.9,3.6,6.2$ and 8.0 respectively. The corresponding slopes which were little less or very close to 0.5 what is the theoretical value for the diffusion controlled processes [17-19], once again showed that the nature of the process is diffusion controlled without the influence of the adsorption.

A
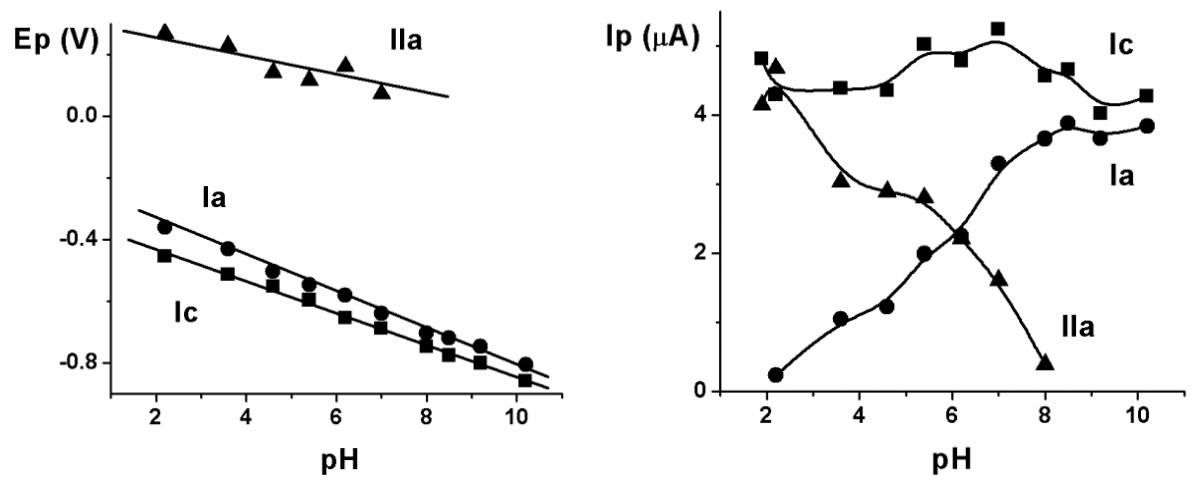

Fig. 3 The influence of pH on: Ic ( $\bullet)$, Ia $(\bullet)$ and IIa $(\boldsymbol{\Delta}) \mathrm{CV}$ peak potential (A) and peak current (B) for $1 \times 10^{-4}$ moldm $^{-3}$ QUI in different buffer solutions; scan rate $100 \mathrm{mV} \mathrm{s}^{-1}$.

The oxidation peak (Ia) exists also at all investigated $\mathrm{pH}$ values, and the peak potential was shifted to more negative values with increasing $\mathrm{pH}$. The linear dependence of $E_{\mathrm{p}} v s . \mathrm{pH}$ $\left(E_{\mathrm{p}, \mathrm{Ia}}=-0.237 \mathrm{~V}-0.057 \mathrm{~V} \times \mathrm{pH}\right)$ with slopes of $57 \mathrm{mV}$, again suggested the same number of electrons and protons involved in the oxidation process. The peak potential difference between peaks Ic and Ia of $\Delta E_{\mathrm{p}} \sim 80 \mathrm{mV}$, and high diversity in peak current intensity $\left(I_{\mathrm{p}, \mathrm{Ic}} \sim\right.$ $2-4 \times I_{\mathrm{p}, \mathrm{Ia}}$ at $\left.\mathrm{pH} \leq 7.0\right)$ indicate a quasi-reversible reaction in acidic and neutral solutions. 
These differences were decreased at $\mathrm{pH} \geq 8.0\left(\Delta E_{\mathrm{p}} \sim 30 \mathrm{mV}\right.$, and $\left.I_{\mathrm{p}, \text { Ic }} \sim I_{\mathrm{p}, \mathrm{Ia}}\right)($ Fig 3A, 3B $)$, leading to the conclusion that the reaction is reaching reversibility in alkaline medium.

Second oxidation peak (IIa) is present at $\mathrm{pH} \leq 8$. Results indicate that the process is irreversible and diffusion controlled. When recording the cyclic voltammograms starting from $0.0 \mathrm{~V}$, going to positive potentials, and reversing to negative, the anodic peak IIa was not present in the first scan, but it appeared in the second and third scan (Figure 2A). The influence of the $\mathrm{pH}$ on this peak potential resulted in the shift to the less positive potentials with increasing of $\mathrm{pH}: E_{\mathrm{p}, \mathrm{IIa}}=0.383 \mathrm{~V}-0.049 \mathrm{~V} \times \mathrm{pH}$ (Figure 3A). The obtained slope is $49 \mathrm{mV}$ per $\mathrm{pH}$, which is close to the theoretical value of $59 \mathrm{mV}$ per $\mathrm{pH}$ for the transfer of the same number of electrons and protons in an electrode process. The peak current intensity dramatically decreased at $\mathrm{pH}>7.0$ and further increasing of $\mathrm{pH}$ above $\mathrm{pH} 8$, resulted in disappearance of this peak. This behavior is in accordance with the increase of the reversibility of the process represented with peaks Ic and Ia. In acid medium where reduction process is not fully reversible, peak IIa may correspond to the oxidation of QUI reduction product formed at the GCE surface during the first scan. After achieving the total reversibility of the redox process represented by peaks Ic and Ia, peak IIa could not be formed any more.

\subsection{Evaluation of kinetic parameters}

The effect of scan rate on the cyclic voltammetric response of QUI was monitored at different pHs. As already mentioned, for a diffusion-controlled irreversible and quasi reversible system $\left|E_{\mathrm{p}}-E_{\mathrm{p} 1 / 2}\right|=47.7 /\left(\alpha \mathrm{n}_{\alpha}\right)$, where $\alpha$ is the charge transfer coefficient, and $\mathrm{n}_{\alpha}$ the number of the electrons in the rate determining step [16]. The values of $\alpha \mathrm{n}_{\alpha}$ were calculated for different $\mathrm{pH}$ values and the obtained values are presented in Table 1.

Increasing the scan rate $(v)$, the current of peak Ic was increased linearly with the square root of $v$. The value of diffusion coefficient (D) was evaluated from the slope of the plot of $I_{\mathrm{pc}}$ versus square root of scan rate [20], by applying the commonly used Randles-Sevcik equation (1). Calculus was performed by taking that $\mathrm{n}=2$ (see Sections 3.1. and 3.3.).

$$
\mathrm{I}_{\mathrm{p}}=\left(2.99 \times 10^{5}\right) \mathrm{n}\left(\alpha \mathrm{n}_{\alpha}\right)^{1 / 2}+\operatorname{ACD}^{1 / 2} v^{1 / 2}
$$

where, $I_{\mathrm{p}}$ represents peak current, $\mathrm{n}$ is the number of electrons transferred during the reduction, A the area of electrode in $\mathrm{cm}^{2}, \mathrm{C}$ concentration of compound in molcm $\mathrm{cm}^{-3}, \mathrm{D}$ diffusion coefficient in $\mathrm{cm}^{2} \mathrm{~s}^{-1}$ and $v$ is scan rate in $\mathrm{Vs}^{-1}$. The values of obtained diffusion coefficient of QUI at different $\mathrm{pH}$ values are given in Table 1.

Increasing the scan rate, the potential of peak Ic was slightly shifted to more negative values. Using $\alpha \mathrm{n}_{\alpha}$ and $\mathrm{D}$ values obtained from the above equation, the rate constant $\left(\mathrm{k}_{\mathrm{s}}\right)$ of QUI was evaluated from the plot of $E_{\mathrm{p}}$ versus $\ln \alpha \mathrm{n}_{\mathrm{a}} v$ by employing equation (2) [21].

$$
\mathrm{E}_{\mathrm{p}}=-1.14\left(\frac{\mathrm{RT}}{\alpha \mathrm{n}_{\alpha} \mathrm{F}}\right)+\left(\frac{\mathrm{RT}}{\alpha \mathrm{n}_{\alpha} \mathrm{F}}\right) \ln \left(\frac{\mathrm{k}_{\mathrm{s}}}{\sqrt{\mathrm{D}}}\right)-\left(\frac{\mathrm{RT}}{2 \alpha \mathrm{n}_{\alpha} \mathrm{F}}\right) \ln \left(\alpha \mathrm{n}_{\alpha} v\right)
$$

Where the slope is equal to $\frac{\mathrm{RT}}{2 \alpha \mathrm{n}_{\alpha} \mathrm{F}}$, and intercept $=-1.14\left(\frac{\mathrm{RT}}{\alpha \mathrm{n}_{\alpha} \mathrm{F}}\right)+\left(\frac{\mathrm{RT}}{\alpha \mathrm{\alpha n}_{\alpha} \mathrm{F}}\right) \ln \left(\frac{\mathrm{k}_{\mathrm{s}}}{\sqrt{\mathrm{D}}}\right)$. By dividing intercept with slope,

$$
\frac{\text { Intercept }}{\text { Slope }}=-2.28+2 \ln \frac{\mathrm{k}_{\mathrm{s}}}{\sqrt{\mathrm{D}}}
$$

the values of $\mathrm{k}_{\mathrm{s}}$ were determined, and summarized in Table 1 . 
Using the same method, parameters $\alpha \mathrm{n}_{\alpha}, \mathrm{D}$ and $\mathrm{k}_{\mathrm{s}}$ were determined for QUI oxidation process, considering $\mathrm{n}=1$ for second anodic peak, IIa. All results are presented in Table1.

Anodic and cathodic shift in reduction and oxidation peaks induced by increasing scan rate indicated both processes to be controlled by mass transport. The shift in peak potential with increase in scan rate is the evidence for the irreversible nature of the redox process $[22,23]$.

Table 1 Kinetic parameters for reduction and oxidation processes of QUI

\begin{tabular}{cccccccc}
\hline Peak & $\mathrm{pH}$ & $\mathrm{E}_{\mathrm{p}}-\mathrm{E}_{\mathrm{p} 1 / 2}(\mathrm{~V})$ & $\alpha \mathrm{n}_{\alpha}$ & $\mathrm{D}\left(\mathrm{cm}^{2} \mathrm{~s}^{-1}\right)$ & $\mathrm{k}_{\mathrm{s}}\left(\mathrm{cms}^{-1}\right)$ & $\mathrm{n}$ & $\mathrm{p}$ \\
\hline \multirow{6}{*}{$\mathrm{I}_{\mathrm{c}}$} & 1.9 & 0.064 & 0.74 & $6.82 \times 10^{-6}$ & $8.19 \times 10^{-12}$ & 2 & 2 \\
& 3.6 & 0.058 & 0.82 & $7.84 \times 10^{-6}$ & $5.41 \times 10^{-15}$ & 2 & 2 \\
& 6.2 & 0.040 & 1.19 & $1.04 \times 10^{-5}$ & $2.09 \times 10^{-19}$ & 2 & 2 \\
& 8.0 & 0.030 & 1.59 & $6.51 \times 10^{-6}$ & $1.71 \times 10^{-24}$ & 2 & 2 \\
\hline \multirow{3}{*}{$\mathrm{II}_{\mathrm{a}}$} & 1.9 & 0.076 & 0.63 & $1.32 \times 10^{-5}$ & $6.81 \times 10^{-13}$ & 1 & 1 \\
& 3.6 & 0.081 & 0.59 & $1.93 \times 10^{-5}$ & $4.02 \times 10^{-6}$ & 1 & 1 \\
& 6.2 & 0.090 & 0.53 & $1.64 \times 10^{-5}$ & $4.23 \times 10^{-5}$ & 1 & 1 \\
& 8.0 & 0.140 & 0.32 & $1.13 \times 10^{-7}$ & $5.50 \times 10^{-5}$ & 1 & 1 \\
\hline
\end{tabular}

Increasing the scan rate from 10 to $100 \mathrm{mVs}^{-1}$, the potential of peak Ic was slightly shifted to more negative values, but the value of this shift decreased with the increasing of $\mathrm{pH}$ from $30 \mathrm{mV}$ at $\mathrm{pH} 2$ to $5 \mathrm{mV}$ at $\mathrm{pH}$. This is probably caused by the increasing degree of the reversibility of the process. On the other hand, the potential shift for peak IIa is much more pronounced reaching the value of $80 \mathrm{mV}$ at $\mathrm{pH} 8$, proving the irreversible nature of the process.

These results are in accordance with the obtained values of the heterogeneous rate constants, $\mathrm{k}_{\mathrm{s}}$. The very small value of $\mathrm{k}_{\mathrm{s}}$ for the cathodic peak Ic indicates the electrochemical process to be very slow, with decreasing of $\mathrm{k}_{\mathrm{s}}$ with increasing of the $\mathrm{pH}$. At the same time, obtained values of $\mathrm{k}_{\mathrm{s}}$ for the oxidation process (IIa) are increasing.

Heterogeneous rate constant $\left(\mathrm{k}_{\mathrm{s}}\right)$ is an important diagnostic criterion for predicting the nature of a redox process. The rate of the electron transfer reactions is strongly dependent on $\mathrm{pH}$ especially at systems in which chemical reactions precede or follow electron transfer provided such reactions that are either rapid or slow compared to the rate constant for electron transfer. This behavior is clearly evident in QUI redox mechanism. For reduction process represented with peak Ic which consumes two protons, it is evident that the values of the rate constant are increasing with the decrease of $\mathrm{pH}$.

In the case of QUI oxidation process which is accompanied with deprotonation, the lowest value of $\mathrm{k}_{\mathrm{s}}$ obtained at $\mathrm{pH} 1.9$ is probably due to the high concentration of $\mathrm{H}^{+}$ions present in such acid medium, making the deprotonation process hard. It is in accordance with the $E_{\mathrm{p}, I I a} v s$. $\mathrm{pH}$ dependence. The peak potential is shifted to lower values with increased $\mathrm{pH}$, suggesting that potential energy barrier height has the largest value in acid medium, making circumstantially the electron transfer the slowest at this $\mathrm{pH}$. With the increasing of $\mathrm{pH}$ the rate of deprotonation increased. These results also indicate that at $\mathrm{pH} 1.9$ the deprotonation might be the rate determining step. 


\subsection{Redox mechanism}

The obtained results showed that QUI undergoes redox process represented by peaks Ic and Ia, followed by the oxidation of the reduction product represented by peak IIa.

To confirm the number of electrons involved in those processes and to propose effective redox mechanism, DPV of QUI was carried out at selected $\mathrm{pH}$ values in the range from 2.0 to 10.0. Average half peak width values for reduction (Ic) and oxidation (Ia) peaks were found to be $60 \mathrm{mV}$, and for oxidation IIa peak $120 \mathrm{mV}$. Number of electrons involved in each electrode process was determined at different $\mathrm{pH}$ values by using the equation 4 [24],

$$
\mathrm{W}_{1 / 2}=\frac{3.52 \mathrm{RT}}{\alpha \mathrm{nF}}
$$

and the results are presented in Table 1. According to CV results (section 3.1.) the same number of electrons and protons are involved in all investigated processes and these are also listed in the Table 1.

According to presented results, it seems that the reduction of QUI occurs as one step quasi reversible reaction in acid and neutral medium, reaching the reversibility in alkaline solutions, always involving the transfer of two electrons and two protons.

According to the postulated reduction mechanism of varenicline [25], and brimonidine [10] at GCE it can be assumed that similar reversible reduction of QUI happens at the pyrazine ring moiety, forming a dihydro-derivative, as in the case of other compounds containing the pyrazine ring [26-30]. The proposed mechanism is presented in the Scheme 1.

The appearance of the anodic peaks Ia and IIa in the reverse scan corresponds to oxidation of QUI reduction product: peak Ia is a consequence of the re-oxidation to QUI, and peak IIa is due to the formation of a hydroxy-derivative, which is present only in acid and neutral solutions. According to Scheme 1, an intermediary hydroxy-derivative (that would spontaneously isomerize to the more stable lactam-tautomer) is formed in a oneelectron irreversible reaction. The formation of this product has been reported for some compounds with similar structure [27].

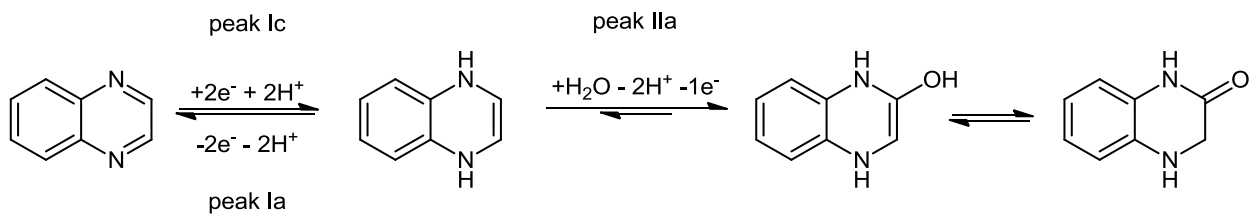

Scheme 1 Electrochemical redox mechanism of QUI.

\section{ConClusions}

The present study has shown that QUI can be reduced and oxidized at a glassy carbon electrode. The reduction of QUI occurs as one step quasi reversible reaction in acid and neutral medium, reaching the reversibility in alkaline solutions, always involving the transfer of two electrons and two protons. The oxidation of its reduced product to a hydroxy-derivative was found to occur in an irreversible, $\mathrm{pH}$ dependent and diffusion 
controlled manner involving the transfer of one electron and one proton. The values of diffusion coefficient and heterogeneous rate constant were successfully evaluated from voltammetric data at different $\mathrm{pH}$ values. Based on the obtained results, redox mechanism of the compound was proposed. The mechanism established could be very useful and recognizable for further studies of structurally similar quinoxaline based compounds, like some important biologically active compounds, antibiotics and antineoplastic drugs.

Acknowledgement. This work was supported by the Ministry of Education, Science and Technological Development of the Republic of Serbia, Project 172033.

\section{REFERENCES}

1. T. Eicher, S. Hauptmann and A. Speicher, The Chemistry of Heterocycles: Structures, Reactions, Synthesis, and Applications 3rd, John Wiley \& Sons, Chichester, 2013.

2. Y.-W. Chin, M.J. Balunas, H.B. Chai and A.D. Kinghorn, Drug discovery from natural sources, The American Association of Pharmaceutical Scientists Journal, 8 (2), E239-E253 (2006).

3. F.E. Koehn and G.T. Carter, The evolving role of natural products in drug discovery, Nature Reviews Drug Discovery, 4 (3), 206-220 (2005).

4. G.A. Cordell, M.L. Quinn-Beattie and N.R. Farnsworth, The potential of alkaloids in drug discovery, Phytotherapy Research, 15 (3), 183-205 (2001).

5. E.H. Hughes and J.V. Shanks, Metabolic engineering of plants for alkaloid production, Metabolic Engineering, 4 (1), 41-48 (2002).

6. R. Dua, S. Shrivastava, S.K. Sonwane and S.K. Srivastava, Pharmacological Significance of Synthetic Heterocycles Scaffold: A Review, Advances in Biological Research, 5 (3), 120-144 (2011).

7. W. Jianlong, Q. Xiangchun, W. Libo, Q. Yi and W. Hegemann, Bioaugmentation as a tool to enhance the removal of refractory compound in coke plant wastewater, Process Biochemistry, 38 (5), 777-781 (2002).

8. R. Soleymani, N. Niakan, S. Tayeb and S. Hakimi, Synthesis of Novel Aryl Quinoxaline Derivatives by New Catalytic Methods, Oriental Journal of Chemistry, 28 (1), 687-701 (2012).

9. V. Radulović, M.M. Aleksić, V. Kapetanović and D. Agbaba, An electroanalytical approach to brimonidine at boron doped diamond electrode based on its extensive voltammetric study, Electroanalysis, 25 (1), 230-236 (2013).

10. M.M. Aleksić, V. Radulović, V. Kapetanović, and D. Agbaba, An extensive study of electrochemical behavior of brimonidine and its determination at glassy carbon electrode, Electrochimica Acta, 106, 75-81 (2013).

11. A.K. Patidar, M. Jeyakandan, A.K. Mobiya and G. Selvam, Exploring Potential of Quinoxaline Moiety, International Journal of PharmTech Research, 3 (1), 386-392 (2011).

12. M. Tagaki and S. Ono, Polarographic studies on quinoxalines for the determination of carbonyl groups in starches, Bulletin of the University of Osaka Prefecture, Ser. B., Agriculture and Biology, 21, 77-122 (1969).

13. P. Murray, J. Strier and C. Cavagnol, The Polarography of Quinoxaline, Journal of the American Chemical Society, 79 (16), 4331-4335 (1957).

14. J. Armand, L. Boulares, C. Bellec and J. Pinson, Chemical and electrochemical reduction of pyrazino [2, $3-\mathrm{g}]$ quinoxalines and of their benzo and dibenzo derivatives; the structure of fluorindine and the formation of tetraanion, Canadian Journal of Chemistry, 65 (7), 1619-1623 (1987).

15. D.D. Perrin and B. Dempsey, Buffers of $\mathrm{pH}$ and Metal Ion Control, Laboratory Manuals, Chapman and Hall, London, 1974.

16. C.M.A. Brett and A.M. Oliveira Brett, Electrochemistry. Principles, Methods and Applications, Oxford University Press, UK, 1993

17. D. K. Josser, Cyclic Voltammetry: Simulation and Analysis of reaction mechanisms, VCH Publisher New York (1993).

18. E. Laviron, General expression of the linear potential sweep voltammogram in the case of diffusionless electrochemical systems, Journal of Electroanalytical Chemistry and Interfacial Electrochemistry, 101 (1), 19-28 (1979)

19. E. Laviron, L. Roullier and C. Degrand, A multilayer model for the study of space distributed redox modified electrodes: Part II. Theory and application of linear potential sweep voltammetry for a simple reaction, Journal of Electroanalytical Chemistry, 112 (1), 11-23 (1980). 
20. E. Nosheen, A. Shah, A. Badshah, H. Hussain, R. Qureshi, S. Ali, M. Siddiq and A.M. Khan, Electrochemical oxidation of hydantoins at glassy carbon electrode, Electrochimica Acta, 80, 108-117 (2012).

21. S.A. Yasin, Electrochemical studies and thermodynamic parameters of Citrazinic Azo Dye and its nitro derivatives in DMF aqueous solution dyes, Portugaliae Electrochimica Acta, 24, 23-36 (2006).

22. A.S.A. Khan, R. Ahmed and M.L. Mirza, Evaluation of Catalytic Activity of Pt and Pt-Ru Catalysts for Electro-oxidation of Methanol in Acid Medium by Cyclic Voltammetry, Portugaliae Electrochimica Acta, 27 (4), 429-441 (2009).

23. I. Honma and T. Toda, Temperature Dependence of Kinetics of Methanol Electro-oxidation on Pt-Sn Alloys, Journal of the Electrochemical Society, 150 (12), A1689-A1692 (2003).

24. I. Ali and S. Omanovic, Kinetics of Electrochemical Reduction of NAD+ on a Glassy Carbon Electrode, International Journal of Electrochemical Science, 8, 4283-4304 (2013).

25. M.M. Aleksić, V. Radulović, N. Lijeskić and V. Kapetanović, Electrochemical response and determination of varenicline at boron doped diamond, glassy carbon and hanging mercury electrodes, Current Analytical Chemistry, 8 (1), 133-142 (2012).

26. A.D.R. Pontinha, S.M.A. Jorge, V.C. Diculescu, M. Vivan and A.M. Oliveira-Brett, Antineoplastic drug methotrexate redox mechanism using a glassy carbon electrode, Electroanalysis, 24 (4), 917-923 (2012).

27. V.C. Diculescu, A. Militaru, A. Shah, R. Qureshi, L. Tugulea and A.M. Oliveira-Brett, Redox mechanism of lumazine at a glassy carbon electrode, Journal of Electroanalytical Chemistry, 647, 1-7 (2010).

28. M.S. Ibrahim, Phase-selective a.c. adsorptive stripping voltammetry of lumazine on a hanging mercury drop electrode, Fresenius Journal of Analytical Chemistry, 367 (2), 189-194 (2000).

29. G. Dryhurst, Electrochemistry of Biological Molecules, Academic Press, New York, 1977.

30. J. Lehnen, B.M. White and M.J. Kendrick, Electrochemical studies of biologically-significant pterin compounds, Inorganica Chimica Acta, 167 (2), 257-259 (1990).

\section{ODREĐIVANJE KINETIČKIH PARAMETARA I ISPITIVANJE REDOKS MEHANIZMA HINOKSALINA NA ELEKTRODI OD STAKLASTOG UGLJENIKA}

Elektrohemijsko ponašanje biološki značajnog heterocikličnog jedinjenja hinoksalina (QUI) ispitivano je cikličnom voltametrijom $(\mathrm{CV})$ u rastvorima različitih $\mathrm{pH}$ vrednosti, korišćenjem electrode odstaklastog ugljenika. Redukcija QUI u kiseloj sredini se odigrava kao kvazireverzibilna reakcija, koja u baznoj sredini postaje reverzibilna. Određeni su i razmatrani kinetički parametric elektrodnog procesa kao što su koeficijent $\alpha n_{0}$, difuzioni koeficijent $(D) i$ konstanta brzine $\left(k_{s}\right)$. Na osnovu eksperimentalnih rezultata predložen je mehanizam elektrodne reakcije. $U$ procesu redukcije adiraju se dva elektrona i dva protona na pirazinski prsten hinoksalina i nastaje njegov dihidro derivat. Proizvod redukcije hinoksalina u kiseloj sredini se dalje oksiduje. Ovaj process oksidacije je difuziono kontrolisan, ireverzibilan i odigrava se uz učešće jednog elektrona $i$ jednog protona.

Ključne reči: Hinoksalin, ciklična voltametrija, elektroda od staklastog ugljenika, redoks mehanizam, kinetički parametri 